\title{
THE EFFECTS OF DESEGREGATION ON RACE RELATIONS
}

\author{
Elizabeth G. Cohen* \\ INTRODUCTION
}

This article on the effects of desegregation on interracial attitudes and behavior has three major objectives. The first is to show the relationship between implicit social values and social science research and the utility of such research to legal issues surrounding the desegregation question. The second is to distinguish between empirical questions to which the social scientist can provide useful answers and those empirical questions which social scientists cannot answer-such as whether a forty-five minute bus ride is more harmful than a thirty minute bus ride. ${ }^{1}$ Finally, this article presents an example of the type of research which might prove useful to school officials, lawyers, and others who are involved in developing desegregation plans.

\section{I}

\section{Social Values and Race Relations}

In order for a social scientist to answer a lawyer's question regarding the harmful consequences of desegregation, the meaning of the term "harmful" will have to be developed first, by specification of the underlying values to be maximized. If overt physical violence is minimal, yet black children experience persistent name-calling, teasing, and rejection, does this constitute harm? And how much harm has to be done before there is a sufficient basis to question the "costs" of maximizing the value goal of desegregation? The social scientist can aid in the articulation of implicit values and the possible consequences which can result from maximizing one particular value while incurring other social costs.

Also relevant to the problem of court-ordered desegregation is the issue of whether some desegregated schools, through planned social change, are able to achieve that state of interracial behavior in which blacks and whites are able to relate to each other as people rather than as members of racial groups. Such

\footnotetext{
* Professor and Direcor of the Environment for the Teaching Program. Stanford Lniversity School of Education. This article is based in part upon research conducted under Contract No. OEC 9-71-0037 (508) with the National Institute of Education. Additional support was provided by the Stanford School of Education, Stanford Center for Research and Development in Teaching, NiE Contract No. NE-C-00-3-0062. The views expressed herein do not necessarily reflect the position. policy, or endorsement of the National Institute of Education.

1. See Swann v. Charlote-Mecklenburg Bd. of Fduc. 402 U.S. 1. $30-31$ (1971): Nurthcross v Board of Educ. of Memphis City Schools. 489 F.2d 15. 16-17 (61h Cir. 1973), cert. denied. 414 L.S $1022(1974)$
} 
educational planning might then be taken into account in developing desegregation plans in response to a court order.

The implicit value goal of research on the effects of desegregation is a broad concern with social integration. If racial conflict and racial separatism grow too pronounced, researchers apparently feel that their concept of an integrated American society is threatened. In a certain sense, children are being asked to solve the problems of integration which their parents have been unable to handle in society at large. In addition, the school-one of the most conservative institutions in society-is being asked to bear the costs of social change.

A narrower value concern is increasing the opportunity for upward mobility of those minorities residentially segregated-increasing opportunity through contact with the dominant majority. Another value concern is that white children be educated as to the falsity and undesirability of prejudicial and stereotypical thinking to encourage them to behave toward blacks in an egalitarian and non-discriminatory manner. The favorable effect on whites of a desegregation process appears to be a value goal discussed only by social scientists, apparently absent from legal ${ }^{2}$ and political considerations. Finally, the issue of interracial interaction and acceptance appears to be related to the question of how integration might improve black academic achievement levels. In order to maximize this goal of black achievement, some argue that black children must associate with achieving white children. ${ }^{3}$

The importance of articulating these implicit value goals is inextricably tied to any evaluation of the available social science literature dealing with the effects of desegregation on race relations. Such research can then be evaluated in terms of its effectiveness in attaining certain goals of the particular researcher-such as the diminution of white prejudice. Alternatively, the research can be evaluated in terms of its relationship to concerns of the legal system-such as reduction of the level of interracial tension and conflict in desegregated schools. However, if the available literature is evaluated from this

2. Dr. Kenneth Clark, who was one of the compilers of the social science brief submitted to the Supreme Court in Brown v. Board of Educ., 347 U.S. 483 (1954), has commented on the Supreme Court's failure to consider this issue:

Ironically, the U.S. Supreme Court, when it handed down its decision in 1954, was in possession of evidence which attempted to pinpoint and to specify the type of damage which was done to white children as a consequence of racially segregated schools in consequence of a racially segregated society.

. [The Court] ... ignore[d] the materials which we presented to it on the damage to white children.

Hearings on Equal Educational Opportunity Before the Senate Select Comm. on Equal Educational Opportunity, 91 st Cong., 2d Sess., pt. la, at 73 (1970).

One court, quite recently, has noted the harm to whites from a segregated system: "Although the principal victims of a racially segregated education are the minority students, it is no less true that racially segregated schools inflict considerable harm on white students and society generally." Hart v. Community School Bd., 383 F. Supp. 699, 740 (E.D.N.Y. 1974).

3. J. Coleman, Equality of Educational Opportunity 307 (1966); R. Crain \& C. Rossell, Evaluating School Desegregation Plans Sratistically (1973). 
latter point of view, much of it turns out to be irrelevant because the research has been based on other value concerns. For example, researchers who are interested in diminishing white prejudice often use a survey questionnaire methodology designed to measure underlying interracial attitudes and tolerance rather than interracial behavior. Parents, the courts, and policy makers, however, may be much more interested in interracial behavior, i.e. whether any interracial contact takes place within the desegregated school and how the groups relate to each other. Unfortunately, the relationship between measures of the extent of prejudice and the likelihood of positive social relationships between the races is little understood. Therefore, the majority of the studies using the survey questionnaire methodology, no matter how well designed or carried out, are not of great utility to lawyers or policy makers interested in interracial behavior.

In addition to analyses of white prejudice, researchers resort to sociometric criteria in order to judge the success of the desegregation process. Thus the subjects of the study would be asked to select class members who are friends or with whom they would enjoy social relationships. Insofar as a choice of social partners is a measure of successful contact between the two social groups, this would seem to be a reasonable questionnaire device. However, insofar as the use of sociometric devices implies that the desired end-state is one of ties of friendship between masses of black and white students, we are using indicators of an outcome which is not only unrealistic but also only weakly related either to the researcher's value goals of social integration or to the court's goals of an orderly desegregation process. The mechanism of desegregation is not intended to create universal love and brotherhood. The goal of the desegregation process is a reasonable degree of social integration and a lack of overt conflict whereby blacks and whites, given an objective important to both, can trust each other and listen to each other sufficiently well to complete the task at hand, whether it be a vocational task, an educational task, or a political task.

It should be kept in mind that the two most important evaluation criteria in considering the usefulness of social science to the courts are pertinence of research findings to underlying value issues under scrutiny in the courts, and the extent to which there is sufficient information upon which to establish a cause-effect relationship between the desegregation process and certain favorable or unfavorable outcomes. In reviewing the social science research on school desegregation, I will attempt to specify the implicit value goals involved. The reader can then evaluate the research in terms of its relevance to particular value issues deemed critical.

\section{II}

\section{Asking Social Scientists Answerable Questions}

Even if social scientists and lawyers were to engage in a dialogue long before cases were actually brought to court, and the value concerns were clearly 
separated from the purely empirical questions, there would remain a very serious problem. Many of the empirical questions which lawyers ask are not answerable with a sufficient degree of certainty given present theories and methodology. For example, suppose the lawyers were to ask these three significant questions of the social scientist: First, assuming that a major goal is improved social integration of black and white members of American society, will school desegregation improve racial integration? Secondly, how much will it improve racial integration? And thirdly, how can the desegregation process be carried out in such a way as to maximize the chances of interracial harmony? This section of the article attempts to describe the criteria used to evaluate whether or not the basic questions being posed are answerable with a satisfactory level of certainty.

Why cannot so central a question as whether school desegregation will improve racial integration be answered: The problem lies in the cause-effect relationship underlying the question. What is being asked is whether a courtordered change in a school's racial composition will cause an improvement in race relations. Science deals with cause and effect by means of general theories which offer an explanation of how causal variables operate to produce specified effects under certain conditions. Clearly, there are no widely accepted general theories which are applicable to this particular question about desegregation and interracial relationships. We cannot even agree how to characterize school desegregation as a variable which might under certain conditions bring about specified effects. In order to work with a concept like "courtordered desegregation," the social scientist must translate that concept into a different kind of abstraction-it must be conceptualized as a phenomenon for scientific study. But desegregation is a political-legal concept, used in widely differing ways by different courts. And when researchers attempt to locate settings in which to study desegregation, they too differ as 10 what constitutes "desegregation." Some say a school with 10 per cent black students is "desegregated," others a 30 per cent black student population. This disagreement as to what is an operational definition of desegregation reveals an underlying disagreement about what kind of social science phenomenon court-ordered desegregation represents.

Even if there were agreement on this point, however, there still are problems in isolating the effects of a process of desegregation with any degree of certainty. This is because there is no relevant theory as to how the process of desegregation affects interracial attitudes and behavior. Absent an understanding of the cause-effect relationship, researchers do not know what indicators to use or the conditions under which to expect desirable outcomes. As long as social scicntists have no theorctical ideas concerning the effects desegregation brings about and no theoretical framework to dictate which variables should be controlled and which indicators of these variables should be utilized, re- 
searchers will continue to reach conflicting results: some studies will show beneficial effects of desegregation and others harmful effects.

The major criticism of existing research on race relations has been directed to its methodological flaws. Thus the impression is that if only the investigator had used longitudinal data, following groups of students over time, ${ }^{4}$ if only the investigator had used a "matched" control group of segregated students, if only the investigator had controlled variables such as classroom racial balance, staff preparation for desegregation and expectations-then the connection between desegregation and desired effects would have been determined with some certainty.

This article takes a more radical position: the available studies on the effects of desegregation are deficient primarily on theoretical grounds. For instance, there is no way of knowing what changes in social history constitute fundamental changes in the parameters of the process, thus rendering studies done in the 1960 's inapplicable in the 1970 's. This is not to say that research has nothing to contribute toward an understanding of these social issues. It is possible to ask the social scientist questions that are empirical in nature and answerable. There are two different kinds of answerable questions in an interchange between law and social science on the issue of desegregation. The answerable questions differ from the unanswerable questions in that the former are much more concrete and descriptive, or are oriented to explanation and process rather than to unconditional questions about effects. Questions about desegregation and its possible effects fall between useful case studies that can be done of particular school systems undergoing desegregation and basic studies of the conditions under which specified outcomes become nuch more probable.

\section{A. Local Decision-Making Studies}

There are very few studies in the research literature which examine the incidence of overt physical interracial confrontation or the extent to which there is any interracial contact in different schools in a district under a courtordered desegregation plan. Such descriptive studies do not involve propositions about cause and effect. It is possible to construct indices of the outcomes which concern the decision makers without having to develop basic theories, ascertaining only that the sampling of observed conflicts or contacts adequately represents the total of such conflicts or contacts. These case studies are essentially historical rather than scientific; they document what has happened in a sample of desegregated schools in a particular city at a particular point in time.

4. Cross-sectional studies are those based on data collected at one point in time. Relationships are static between people or groups or whatever it is that is being studied at that point in time. longitudinal studies, on the other hand, include at least wo sets of data gathered over a period of time. Usually they are the changes in a particular characteristic of phenomenon over time that are studied. 
Yet such descriptive studies can prove very useful to decision makers in determining which schools need further expert assistance and resources to enhance the effectiveness of the desegregation process.

These studies do not attempt to determine general outcomes of desegregation. Instead they ask the question: are we experiencing much more interracial conflict in School A as compared to School B? If the results indicate this to be the case, some remedial steps may be taken in School A; and the study may be replicated to ascertain whether the desired improvement has been achieved.

\section{B. Process-Oriented Studies}

In contrast to relatively concrete questions which are of prime interest to local decision makers, there are important questions to be answered about the conditions under which interracial contact might be expected to result in desirable interracial attitudes and behavior. These questions become answerable by concentrating on what lawyers, policy makers, and parents agree are desirable outcomes of the desegregation process. If agreement on such desired outcomes can be reached, then questions about which conditions are more likely to achieve these desired outcomes can be answered. This knowledge can then be utilized by lawyers, school officials, and others in formulating desegregation plans. Some of the outcomes of desegregation deemed socially desirable do coincide with other areas of social science. The conditions under which we might expect to produce "equal status behavior" between black and white students-described in greater detail later in this article-is an example.

Jane Mercer has described this kind of useful dialogue succinctly and aptly:5

There are some questions concerning how to achieve those values which can perhaps be answered by applied research. Perhaps we could clarify the difference between the two categories of value questions and empirical scientific questions so that lawyers would not ask social scientists to come up with answers to questions involving value criteria. This would limit us to rather concrete questions: "How do we get from here to there, if we both agree we want to go to there?" Then, in certain circumscribed areas, I think we could say, "Yes, there seem to be ways to get from here to there."

\section{III}

\section{Review of Existing Social Science Research}

This section analyzes the available social science research literature on the relationship of desegregation to interracial attitudes and behavior. In evaluating the state of the knowledge, the implicit value goals are specified where possible and the relevance of the research to attaining those goals as well as its relevance to attaining values of more direct interest to the courts are discussed.

5. Statement made at The Courts, Social Science, and School Desegregation Conference, Hilton Head Island, S.C., Aug. 20, 1974, on file at Law and Contemporary Problems office. 
Secondly, the problem of using correlational studies to make inferences concerning the effects of desegregation without the benefit of explanatory theories is discussed. Finally, special attention is paid to those studies which indicate social processes essential to achieving desired outcomes in desegregated settings.

\section{A. Early Research on Racial Mixing}

In her review of research undertaken between 1937 and 1973 on desegregation and racial prejudice, St. John points out that most studies begin with the assumption that children are racially prejudiced; the researcher seeks to determine whether changes in the school's racial composition will affect that level of prejudice." Pre- 1968 research utilizing questions concerning the race of classmates chosen as friends showed a consistent tendency for in-group preference-or intolerance of other races-to increase with age. ${ }^{7}$ But studies which focus on the effects of interracial contact among children come to conflicting conclusions. A classic early study found that after a two-week interracial camping experience during which whites still preferred whites as friends, there was a significant drop in the extent to which these preferences were found. ${ }^{8}$ By contrast, another study found black children in segregated schools and both black and white children in naturally desegregated schools more prejudiced than whites in segregated schools." Similarly, a study of black and white junior high school children in California before and after integration revealed that white children who had experienced integration were less tolerant of Negroes. ${ }^{10}$

An oft-cited study was undertaken for the United States Commission on Civil Rights." Utilizing data collected by the Equality of Educational Opportunity survey ${ }^{12}$ on over 75,000 whites and blacks from grades nine and twelve in the metropolitan Northeast. a preference by students for desegregated schools and friends of other races was found to be positively related to both the number of years students had attended desegregated schools and the present proportion of white students in their classrooms. ${ }^{13}$

It was realized relatively early that whether or not school desegregation would have a positive effect on race relations would depend on a number of

6. N. St. Johx, Schodi. Desegregation Olycomes for ChHLdex 65 (1975).

7. Carithers. School Desegregation and Racial Cleavage, 1954-1970: A Revieu of the Literaturt. $26 \mathrm{~J}$. Sociological. Issces 25, 32-35 (1970).

8. Yarrow. Campbell. \& Yarrow. Acquisition of Neu Norms: A Study of Racial Desegregation, $14 \mathrm{~J}$. Sociological Issues 8.27 (1958).

9. Dentler \& Flkind. Intergroup Attitudes, Academic Performanor. and Racial Composition, in THE UrbaN R's (R. Dentler, B. Mackler, \& M. Warshaver eds. 1967).

10. Webster. The Influence of Interrarial Contact on Social Acreptance in a Newly Integrated School, 52

J. Fo. Psychology 292, 295-96 (1961).

11. U.S. Commission on Civil Rights, Racial Isolation in the Public Schools (1967).

12. J. Coleman. supta note 3.

13. See L.S. Commission on Civil Rights. supra note 11. 
factors. The report to the United States Commission on Civil Rights cited such factors as "leadership given by state and local officials, application of the plan to all schools in the community; measures taken to minimize the possibility of racial friction in newly desegregated schools and the desegregation of classes within schools." 14

Criticism of this earlier literature centered on two main points: the first noted the need for some theoretical concepts such as Gordon Allport had put forth on the necessary conditions for the reduction of prejudice as a consequence of "equal status contact"; ${ }^{15}$ and the second reflected a growing dissatisfaction with the methodology used in these studies. Some social scientists ${ }^{16}$ contend that this research wrongfully assumes that integration is "unsuccessful" if any type of interracial contact fails to be associated with reduction in prejudice, maintaining that this is a misreading of Allport's theory which specified that only if certain conditions are met will contact result in lessened prejudice. ${ }^{17}$ Thus it has been argued that studies of integration should take into account whether or not particular desegregated schools have met these conditions. ${ }^{18} \mathrm{~A}$ study in which the entire literature on intergroup contact was reviewed concluded that changes in ethnic relations do occur following contact, but that if the conditions are unfavorable, intergroup tension and prejudice increase, and if conditions are favorable, there may be a diminution of prejudice. ${ }^{19}$ Other criticisms of these early studies can be summarized as follows:

1. The studies are cross-sectional rather than longitudinal, so that one cannot document the hypothesized improvement or deterioration in interracial relations over time. ${ }^{20}$

2. They do not have an appropriate comparison or control group, so there is no way of telling whether or not a group of students not experiencing desegregation would show exactly the same attitudes or change in attitudes.

3. Different studies use different measures of prejudice.

4. Even if there is an attempt to follow a sample over time, the desegregation process may have to take effect over a much longer period of time before favorable effects are shown.

5. Many important variables such as the socioeconomic status of the student, the racial composition of the classroom, or the racial composition of prior schooling are not controlled.

\footnotetext{
14. Id. at 154 .

15. G. Allport, The Nature of Prejudice 280-81 (1954).

16. Se Pettigrew, Useem, Normand \& Smith, Busing: A Review of "The Evidence," 30 PuB. INTEREST 88 (Winter 1973).

17. Id. at 91-93. Bul see Armor. The Evidence on Busing. 28 Pub. INrtkes1 90 (Summer 1972)

18. Pettigrew, Useem. Normand \& Smith, supra note 16. at 93.

19. Amir, Contact Hypothesis in Ethnic Relations, 71 Psychological Bull. 319.338 (1969).

20. See note 4 supra.
} 
B. The Research: 1968-1974

A systematic review of the post- 1968 research literature was undertaken for this article. ${ }^{21}$ There are a number of problems with these more recent studies. First, none of them build upon pre-1968 findings. Despite the suggestions of early studies, the post- 1968 research still fails to take into account the steps schools might have taken to bring about integration as opposed to mere desegregation. Only five of the twenty-four studies reviewed took into account interracial contacts within the schools. In other words, some of the desegregated schools studied may have resegregated within the school or even the classroom by means of tracking or ability grouping. ${ }^{22}$ Only three studies contain detailed information on staff attitudes and the extent to which the staff was prepared for desegregation. Similarly, only one study provides detailed information on curricular changes in preparation for desegregation. Lastly, only one study gives detailed information on the racial composition of the school staff after desegregation has occurred.

The most disappointing aspect of these studies is the fact that little, if any, thought has been given to the sociopolitical context in which the desegregation process occurs. Only two studies deal solely with non-voluntary desegregation, an issue of paramount importance to court litigation. Eight studies deal with various voluntary programs such as the METCO program in the Boston area. ${ }^{23}$ Seven studies contain observations on both voluntary and mandatory situations without any distinction between the two processes of desegregation, and six studies fail even to tell which phenomenon is being studied.

A further difficulty is that none of these studies employ a systematic theoretical framework as an aid in understanding why the desegregation process should have certain consequences or the specification of the conditions under which desegregation leads to certain consequences. ${ }^{24}$ While eight of the

21. A computer search of the Educational Resources Information Center (ERIC) system and of the Psychology Abstracts retrieval system located over 500 references to the effects of desegregation on interracial attitudes and behavior. Sociology Abstracts was also utilized. Many of the references found through ERIC dealt with practical, educational, and political ways of desegregating schools or were historical and impressionistic case studies of how desegregation was undertaken in a particular city. On the other hand, much of the psycho-social research on the effects of desegregation was concerned with the effects of a change in self-concept or in level of aspirations on black students. Thus, much of this material is irrelevant to the topic under discussion. More pertinent were a number of evaluation studies of the desegregation process in particular cities which included measures of interracial attitudes and behavior.

The methodology was as follows: each research report was described, critically evaluated, and coded as to type of dependent variable studied, study design, number and types of controls used, sampling, non-response problems, and presence or absence of explanatory concepts and theories. In all, 24 studies covering interracial attudes and behavior were analyzed.

22. See, e.g. Moses v. Washington Parish School Bd., 456 F.2d 1285 (5th Cir. 1972), cert. denied. 409 U.S. 1013 (1972).

23. The METCO program, which originated in 1966 , is a voluntary busing program which places a relatively small number of black students from Boston in selected white suburban schools.

24. The only possible exception is a study which attempted to test Allport's contact hypothesis. 
studies referred to an explanatory concept such as "equal status contact," they failed to integrate it into the study design. A contrast between schools with high amounts of "equal status contact" and those with low amounts should be built into a study of a selected set of schools. Alternatively, an indicator of the concept of "equal status contact" should be introduced in the statistical analysis to see if desired effects of the desegregation process are associated with its presence. Twelve studies do use such relatively concrete explanatory concepts as the presence or absence of teacher leadership. Only seven studies involved measures of interracial behavior, observed or reported. The bulk of the studies, twenty-two of the twenty-four, used survey questionnaire measures of attitudes. Four utilized sociometric criteria of interracial friendship.

Almost all of the studies can be faulted on their basic design. Only four studies are longitudinal, i.e., the same subjects were studied before and after the desegregation process took place. Ten studies attempt to approximate a longitudinal design by taking several cross-sections of the schools being studied at various times during the desegregation process. The principal improvement over pre-1968 research is the inclusion of a control or comparison group of some type in seventeen of the studies.

Controlling certain variables, such as social class, presented many problems. Thirteen of the twenty-four studies have some control for the social class of the schools being compared, but only eight studies control the social class of the individuals being studied. Issues of race and social class are closely intertwined, and studies of desegregation must try to disentangle the effects of these two major variables.

Although 14 studies utilized more than 500 subjects and 9 used between 100 and 500 , only 5 of these studies used random-sampling. The non-response rates on questionnaire items were also severe: seven studies report less than a 25 per cent non-response rate; three report a 25 to 50 per cent non-response rate, while one reports more than a 50 per cent non-response rate. Thirteen of the studies fail even to indicate the extent of the rate of non-responses to questionnaires. The presence of non-response rates is quite serious when one is trying to describe negative attitudes between social groups; for example, one can make a reasonable argument that students who are the most hostile and negative toward others are most likely to fail to respond to questionnaires.

Lewis \& S1. John. Contribution of Cross-Racial Friendship to Minority Group Achirvement in Desegregated Classrooms, 37 Socionetry 79 (1974).

Allports contact hypothesis is as follows:

Contacts that bring knowledge and acquaintance are likely to engender sounder beliefs about minority groups . . . Prejudice ... may be reduced by equal status contact between majority and minority groups in the pursuit of common goals. The effect is greatly enhanced if this contact is sanctioned by institutional supports (i.e. by law. custom. or local atmosphere), and if it is of a sort that leads to the perception of common interests and common humanity between members of the two groups.

Allport. The Nature of Prejudice 268, 281 (1954). 


\section{Interpretation of the Results}

If the findings of these studies are in part attributable to uncontrolled variables or are an artifact of the nature of the population selected for busing programs, or if the observed correlation has no relation to a hypothetical causal process, then the results of these studies cannot be easily summarized. In view of these difficulties, then, can anything be learned from these studies about the extent to which desegregated schools meet conditions for equal status contact; whether desegregation can, under specified conditions, become a setting for interracial interaction which in turn leads to reduced racial prejudice and stereotyping; how students respond to the change in student body composition in newly desegregated schools; whether there are changes as time passes; and finally, whether peer acceptance of blacks leads to improved black achievement?

With regard to the conditions surrounding contact between the races which will decrease prejudices, these desegregation studies represent no advance in knowledge as to a causal theory. Nor is there anything in the research that provides some basis for testing assumptions about the process by which integration can assist black achievement through the medium of peer acceptance.

Though the existing research is inadequate in the ways I have described, this does not mean that it can or should be ignored or undervalued. In the following section, research on the effects of desegregation on race relations is reviewed, with particular attention to work completed since 1968. First, studies relating to the acceptance of desegregation by students-their preferences with respect to interracial contact and racial prejudice-are examined. Second, a review is undertaken of those studies not concerned primarily with interracial acceptance per se, but with the implicit theory held by many social scientists and policy makers: that if blacks are accepted by whites in more achievementoriented white classrooms, their achievement will improve. Finally, studies which deal explicitly with the conditions that seem to enhance race relations are examined as well as the implications of these findings for strategies of interracial mixing in schools.

\section{Desegregation and Reducing White Prejudice}

Some forty-one studies were examined by St. John with regard to their findings of diminution in prejudice among whites and blacks as measured by tests of attitudes and friendliness. ${ }^{25}$ For either race, positive findings are somewhat less common than negative findings, and in many cases there is no effect or the effects are mixed. ${ }^{26}$

It is also apparent that the direction of findings is as often contradictory as it is consistent for the wo races. Sometimes desegregation is reported to have

25. N. St. Johs, supra note 6.

26. Id. at $67-68$. 
ameliorated the prejudice of whites but intensified that of blacks, sometimes the reverse. ${ }^{27}$

What is more important, St. John breaks these studies down according to various criteria, seeking consistent results within certain subcategories. For example, she asks: are the results consistent within categories if we divide up the schools studies as to whether they represent integrated neighborhood housing patterns, voluntary or mandated desegregation? When the findings of these studies are classified according to the manner in which desegregation was accomplished, it appears that whites who deliberately choose desegregated programs may have had favorable attitudes to start with. In general, however, self-selection does not seem to have regularly resulted in more positive findings. "Findings are contradictory regardless of whether desegregation was 'natural,' mandatory or voluntary." 28 Desegregation in the South seems to be associated with negative interracial attitudes by students more often than desegregation in the North. ${ }^{29}$ However, it could be that increasing prejudice can be an indication that the community climate, rather than interracial contact, is affecting attitudes. ${ }^{30}$

In a similar manner, studies which are longitudinal in design are compared with those that are cross-sectional, finding that cross-sectional studies without "before and after" measurements indicate attitudinal gains among white children. Longitudinal studies with control groups, however, indicate attitudinal losses. ${ }^{31}$ If these studies are categorized as to whether they deal with sociometric or attitudinal indices, equally mixed results are revealed. By taking into account background characteristics of the students involved, St. John finds a number of studies that report difficulties experienced by black females as contrasted to black males in the desegregation process. ${ }^{32}$ Too few studies have utilized proper controls on socioeconomic status, but several studies suggest that results for desegregation are more favorable when the socioeconomic backgrounds of the two races are substantially similar. ${ }^{33}$ Younger children appear to benefit from desegregation somewhat more than older children. ${ }^{34}$

The studies that have been analyzed for this article appear to yield the same mixed results as the studies reviewed by St. John. Following is a sample of the studies of interracial attitude and acceptance that have been reviewed:

1. A study of the willingness of children to associate with various social

27. N. ST. JoHs, supra note 6 , at 68 .

28. N. ST. JoHN, supra note 6 , at 76.

29. Id.

30. See E. Campbell, The Attitude Effects of Educational Desegregation in a Southern Community. 1956 (unpublished doctoral dissertation. Vanderbilt University) referred 10 in N. ST. JOHX. supra note 6. at 76 .

31. N. ST. JoHn, supra note 6. at 73 .

32. N. ST. JoHs, supra note 6 , at $78,110$.

33. N. ST. Joнn. supra note 6 , at 126.

34. N. ST. JoHN supra note 6 , at 77. 
groups was undertaken in a de facto segregated school, an all-white school, and a nonsegregated school. Whites attending nonsegregated schools were more willing to associate with blacks than whites in segregated schools. Negroes attending nonsegregated schools were also more accepting of whites than Negroes in segregated schools. On a scale of aggression and achievement, white children saw blacks as more aggressive and as non-achievers if they had classroom contact than if they had no classroom contact. ${ }^{35}$

2. A comparison of students from rural white high schools in an all white area of Alabama with an integrated school (6 per cent blacks since 1965), also in Alabama, indicated that white students in the integrated school were significantly more "prejudiced" than whites in the segregated school. ${ }^{36}$

3. A public school in the Atlanta area with only seven black students enrolled was compared with a Catholic parochial school with a black population of 28 per cent. Only 56 out of 101 volunteers completed the questionnaires measuring acceptance or rejection of prejudicial statements about a number of religious, racial, and behavioral out-groups. The analysis indicated that students who attended the integrated school for four years were significantly less prejudiced toward all the outgroups than students in the all-white school. The researchers acknowledge the grave problem of the special selection of white parents who choose to send their children to the integrated inner city school. ${ }^{37}$

4. A sociometric measure and measures of classroom preference for white and black teachers and students, according to the extent to which the racial balance of the classroom in which the child is located reflects the racial composition of the entire school, indicate that the polarization of racial friendship grouping was only slightly less extreme in racially balanced as opposed to unbalanced classes. ${ }^{38} \mathrm{~A}$ study of third graders in racially mixed elementary schools in a large eastern city school district - eliminating slum and upper class schools and schools in which one race comprised less than 25 per cent or more than 75 per cent of the population-showed that race strongly affects choice of friends.

5. In an investigation of the southern response to desegregation, a study was undertaken of two high schools in two rural Georgia counties or-

35. See D. Singer, Interracial Attitudes of Negro and White 5 th Grade Children in Segregated and Unsegregated Schools, 1966 (unpublished doctoral dissertation, Columbia University).

36. See Wade \& Wilson. Relatively Low Prejudice in a Racially Isolated Group. 28 Psichological REP. 871 (1971).

37. See Patterson \& Smits, Reactions of Inner-City and Suburban Adolescents to Three Minority Groups, $80 \mathrm{~J}$. Psychology 127, (1972).

38. See Koslin, Koslin, Pargament, \& Waxman, Classroom Racial Balance and Students Interracial Attitudes, 45 Sociologr of ED. 386 (1972). 
dered to desegregate by the fall of $1970 .{ }^{39}$ Students were administered questionnaires before the desegregation process began and one year after the process of desegregation was underway. Black and white students were found to differ from each other in their expectations and evaluations of desegregation. Before desegregation, 80 per cent of the whites expected maintenance of racial separation within the desegregated schools. Seventeen per cent of the blacks did not expect that desegregation would really come about, but only 45 per cent expected resegregation within the school if it were to be desegregated. A year after the schools were desegregated, only one-fifth of both races report the existence of interracial contact on a social level. There was a decline in positive evaluations of desegregation among blacks-whereas before desegregation, 44 per cent had believed they would receive a better education in the integrated school; a year after the process of desegregation had begun, only 9 per cent felt that their education had improved. The proportion of black students who felt that desegregation served a useful purpose dropped from 75 per cent to 35 per cent, while there was either no change or only a slight improvement in white evaluations of integration.

6. Another southern study ${ }^{40}$ utilized a random sample of blacks and whites from a cross-section of rural and urban secondary schools in western Tennessee, an area highly resistant to racial desegregation. Students attending newly desegregated schools, segregated schools, and schools desegregated for a year or more were compared. The wisdom of including a segregated control group is shown by the researchers' finding that the black students' satisfaction with school, including their perception of "kindness of other pupils," went down in all three kinds of settings over the course of the school year.

In general, studies of integration in northern cities present a very mixed picture with results frequently quite different for white and black students, and for male and female students. A well designed longitudinal study of elementary and secondary classrooms in Kalamazoo, Michigan ${ }^{41}$ during a two-way busing desegregation process-with data collected just prior to desegregation and one year later-revealed that the opinions of all students were significantly less positive after desegregation than before on such questionnaire items as "class

39. See Bullock \& Braxton, The Coming of School Desegregation: A Before and After Study of Black and White Student Perceptions, 54 Social Science Q. 132 (1973).

40. See Williams \& Venditti, Effect of Academic Integration on Southem Negro Students' Expressed Satisfaction With School, 79 J. Social Psychology 203 (1969); Williams \& Venditti, Effect of Academic Desegregation on Southern White Students Expressed Satisfaction With School. 38 J. NEcro E.D. 338 (1969).

41. See W. Coats, A Longitudinal Survey of Desegregation in Kalamazoo. Michigan, Sept. 7 , 1972 (paper presented at the American Psychological Association Annual Convention, Honolulu, Hawaii). 
orderly," "class fun," "teacher likes you," and "liking for school." White secondary students' overall evaluation was not strongly affected as measured by the item concerning friendliness of other students, but they were less likely to report that they were learning a lot. The attitudes of white elementary students showed only one statistically significant change-they saw the students in their class as friendlier.

A study based on questionnaires addressed to graduating high school seniors in Berkeley, California probably involves the longest period of desegregation of any of the studies reviewed here, inasmuch as the school system had been desegregated since the graduating seniors had been in the seventh grade. ${ }^{42}$ Questionnaires had been addressed to these students when they were in junior high school when desegregation was initiated. Since the first questionnaire, an increase in reported interracial mixing was noted. Some of this increase appears to be due to cross-sex mixing: black males and white females are reported to date often, but white males and black females are reported as dating infrequently. ${ }^{43}$ There are also important class differences associated with interracial mixing; given a more middle class black population, the number of white and Asian friends reported increases. However, among whites, the number of black friends decreases given a more middle class white population. Blacks were more likely to report experiencing aggressive acts than whites; but of the aggressive encounters reported, students saw them as primarily instigated by blacks.

Several evaluations of the effects of Boston's METCO program, involving a voluntary program which buses black children from predominantly black schools in Boston to predominantly white schools in the surrounding suburbs, have been undertaken. ${ }^{44}$ In one study, questionnaires were administered to a random sample of white tenth graders in eight high schools which very small numbers of METCO students had attended for a period of from one to three years. Although a majority of white students were found to favor the program, a highly significant variation exists between the schools. In two of the schools only 43 per cent and 55 per cent of the white students felt the program should be continued. This is a low percentage considering the small number of black newcomers and the northern setting of the study. It is important to recognize the profound difference a particular school context can make in accounting for

42. See Office of Education, U.S. Dep`T of Health, Education and Welfare, follow'up Study of Student Atritudes Toward School Reorganization of the Public Schools in a NORTHER CITY, FINAL REPORT (1972). Unfortunately, the study is weakened by a poor response rate-only 44 per cent of the black students returned their questionnaires.

43. Educators working in desegregated northern settings often comment on the frustration and rage at this state of affairs experienced by black female students, but most researchers do not deal with such delicate and important matters.

44. See Armor, supra note 17; Useem, White Students and Token Desegregation, 10 INTEGRATED ED. 46 (1972); H. Walberg. An Evaluation of an Urban-Suburban School Busing Program on Student. Achievement and Perception of Class Learning Environments. Feb. 1971 (paper presented at annual meeting of the American Educational Research Association. N.Y.). 
different responses to racial mixing. Furthermore, these differences in the METCO study could not be explained by differences in student socioeconomic status, in religion, or prior contact with blacks. ${ }^{45}$

The other two METCO studies both examined data collected on 732 bused children and 352 siblings of these children who stayed behind in their predominantly black schools. Children in both groups were given achievement tests and questionnaires to complete in the fall of the school year in which the program started, and again in the spring. Children in the third through fifth grades who were bused to white suburban schools saw their classes as significantly more satisfying than did their siblings who continued to attend predominantly black schools. ${ }^{46}$ However, a questionnaire given to junior and senior high school students showed that the bused students were significantly more likely to favor the ideology of "black power" and black separatism than the control group. ${ }^{47}$

These studies are in no sense comparable with each other. Any difference in "favorability" toward desegregation that is found may be a consequence of one or more of the following factors: different research designs; different questionnaire items; differences in time and place; or differences in the actual phenomena being studied (racial mixture may actually represent several social phenomena). Within each of these studies, there are important differences between schools, between male and female students, between races, and between classes. These differences both within and between studies suggest that in order to gain any kind of practical understanding of the consequences of desegregation, the social scientist must avoid undertaking studies of this particular type and focus on local decision-making studies or more theoretically oriented studies.

Case studies of individual cities utilize various indicators of attitude changes. Some assume that the most vital variables for measurement are Negro self-concept or achievement motivation, without stopping to examine the murky issues underlying this particular choice of variables. These studies often neglect questions of considerable concern to parents and others such as: How is the process of desegregation proceeding: Is there interracial friction? Are students supportive of the process:

Only one study dealing directly with the relationship between racial hostility and the desegregation process was found. ${ }^{48}$ In this study, black junior and senior high students who were first to desegregate previously all-white schools in the state of Alabama were interviewed. From a list of 500 such students,

\footnotetext{
45. Lseem, supra note 44, at 51.

46. See H. Walberg, supra note 44.

47. Armor, supra note 17. at 103 .

48. So M. Chesler \& P. Segal, Characteristics of Negro Students Attending Previously AllWhite Schools in the Deep South. Sept. 1972 (mimeograph at Institute for Social Research, Lniversily of Michigan).
} 
one-half of the names from each community were randomly selected and interviewed during the summer of 1966. In the initial days and weeks of desegregation, 48 per cent of the black respondents felt they encountered considerable resentment and hostility; they were particularly sensitive to "passive resentment communicated to them through hostile stares, efforts at physical avoidance, laughing and teasing behind their backs and general unfriendliness." ${ }^{49}$ Fifty-six per cent of the respondents said that their white classmates called them derogatory names such as "nigger," "darkie," and "coon." Behavior of whites toward the respondents was by no means uniform, as 36 per cent of the respondents said that the reactions of whites varied, ranging from friendly to hostile. Seventy-four per cent of the black students interviewed reported that at least some whites acted in a friendly way; in a substantial number of the cases, however, these budding relations seemed to generate more negative responses from white peers: other whites sometimes harassed the white students who were friendly to blacks. ${ }^{51}$

Later in the year, a majority of the black students enrolled in the previously all white schools reported that white students were acting differently toward them than at the beginning. Just over half of the changes were in a positive direction-less fighting, rejection, and isolation. However, of those students reporting change over the year-52 per cent of all such students-only half of these changes were in a positive direction meaning that only one-fourth the total population experienced positive changes. The majority of the students. reported contact with whites outside the class, and 75 per cent felt that they had some friends among their white peers.

\section{Improving Black Achievement Through Peer Acceplance}

Interracial relations have not only been of interest because of the value placed on social integration, but they also have been a key link in the argument that integrated schools will improve the achievement levels of black students through their acceptance by high achieving white peers. In an early, highly influential review of evidence as to the effects of desegregation, ${ }^{52}$ Katz argued that friendliness on the part of the white majority group might be helpful to incoming black students in two ways: (1) acceptance by the dominant racial group in the classroom might reduce social threat and raise self-confidence, and (2) acceptance by achievement-oriented peers might increase their influence as role models and lead to adoption of their norms. ${ }^{53}$

This reasoning leads to the proposition that academic success of minority

49. Id.

$50 . \quad I d$.

51. Id.

52. Katz. Reviou of Evidence Relating to Effects of Desegregation on the Intellectual Performance of Negrops, 19 Am. Psichologist 381 (1964).

53. Id. at 382-83. 
group students in interracial classrooms may be contingent upon their acceptance into the majority group peer structure. ${ }^{54}$ A reanalysis of the 1966 Coleman Report's cross-sectional data showed that interracial friendship was a predictor of black achievement only when classrooms were at least half white. ${ }^{55}$ The evidence that acceptance is necessary in order for desegregation to have a positive effect on black achievement is slight. Often cited in discussions of this topic is a study which found that peer status is related to achievement in generally all-white classrooms. One can not be sure, however, whether achievement caused popularity or if popularity caused achievement. ${ }^{56}$

In an effort to disentangle the issues of cause and effect, and to determine how black students' achievement is affected by their popularity among white students, an analysis of a sample of racially integrated Boston elementary classrooms was undertaken. The effects of early academic achievement, early school racial composition, and family socioeconomic status were also taken into account. The results indicated that popularity with whites does contribute to improved achievement levels of blacks. ${ }^{57}$ Even in this study, however, the researchers cannot rule out the possibility that achievement affects popularity rather than popularity affecting achievement. ${ }^{58}$

If popularity is simply a byproduct of achievement in majority white classrooms, then many black children placed in middle class classrooms where they cannot compete for grades will not benefit by desegregation. Even more important, if the underlying reason for this correlation is the fact that majority white classrooms are achievement-oriented while some majority black classrooms are not because there are too many students who have no hope of success in a traditional, middle class curriculum, then one can argue that changing the curriculum in these all-black classrooms so as to encourage success will improve achievement levels, just as easily as one can argue that desegregation will improve achievement levels of blacks.

This argument concerning the importance of acceptance by white peers has assumptions underlying it which are similar to those expressed in the cultural deficit literature. ${ }^{59}$

The cultural deficit literature is basically concerned with explaining why it seems that low-income minority groups have not acquired American middle-

54. See N. St. John \& R. Lewis. Children's Interracial Friendships: An Exploration of the Contact Hypothesis, 1973 (unpublished manuscript at the University of Massachusetts).

55. See J. McPartiand. The Srgregated Student in Desegregated Schools: Sources of Influence on Negro Secondary Students (The Johns Hopkins University Center for the Study of Social Organization of Schools Report No. 21. 1968).

56. See Schmuck. Some Relationship of Peer Liking Patterns in the Classioom to Pupil Attitudes and Achievement. 71 The. School Rev. 337 (1963).

57. See N. Si. John \& R. Lewis, supra note 54.

58. Sep St. John \& Lewis. Race and Sorial Structure of the Elementary Classoom (to be published in Sociology of EDuce in 1975).

59. D. Kirk \& S. Goon, Desegregation: An Examination of the Literature, 1972 (unpublished paper at School of Education, Stanford University). 
class attitudes, values, and behaviors. The problem, according to that literature, is due to the lack of contact low-income minority group children have with American white middle-class children, especially within the schools during their formative years. It is assumed that contact will alleviate the problem... The discrepancy between what middle-class children received as part of their education and that received by low-income children in conjunction with their respective achievement levels seemed to clearly indicate to these authors that one could affect achievement levels by equalizing educational inputs. It is, therefore, assumed that educational inputs would be equalized when there is racial balance.

The failure to recognize the underlying assumption that blacks can only become achievement-oriented by close ties with whites is like the failure to recognize the fears that less educated white parents have concerning busing plans which will send their children back into lower class, black neighborhood schools. ${ }^{60}$ The policy maker is unprepared for the deep resistance to desegregation expressed both by some blacks-particularly the younger intelligentsia and the adherents of Black Power ideology-and by less educated whites. Without explicit attention to the underlying value assumptions, reliance upon social science research evidence may have some unfortunate consequences.

\section{Conditions for Desired Interracial Behavior}

Some commentators have urged that schools be examined not so much in terms of racial composition, but in terms of the conditions necessary for "equal status contact." ${ }^{1}$ It is argued that some desegregated schools are creating conditions far more closely approximating equal status contact than others and that certain conditions are essential before positive effects can be expected from intergroup contact: equal status, common goals, institutional supports, and a non-competitive atmosphere. ${ }^{62}$

Some integrated schools represent conditions in which, rather than being dissipated, racial stereotypes held by blacks and whites are actually reinforced. In some of these schools, black children's relative lack of academic success is interpreted as due to their inherent inferiority, while the white children's relative academic success is attributed to their superiority. Furthermore, in some of these schools, stereotypes of blacks as hostile and dangerous, andustereotypes of whites as untrustworthy and "always trying to put you down," are reinforced. Physical conflict is not the only consequence of such stereotypes; another con-

60. See S. Rubin, Busing and Backlash (1972).

61. See Pettigrew, Useem, Normand \& Smith, supra note 16.

62. Id. at 91 . This argument is based on a much earlier study in which Allport set forth certain conditions for attaining "equal status contact." G. Altport, supra note 15.

Some of the problems with Allport's theory are discussed in C. Riordan. The Conditions and Effects of Equal Status Contacts: A Critical Review, 1974 (unpublished paper at Providence College, Providence, R.I.). For example, does "equal status" nean that individuals must be of the same class if they are of different races? Must all of Allports conditions be met before the desired results of intergroup contact are obtained, or is it sufficient if only some of them are met: 
sequence can be the failure of black students to make a significant contribution to the interaction, and the tendency of whites to dominate the interaction.

One study provides some remarkable evidence to the effect that such white-dominated interaction can and does take place among interracial groups of children who have attended integrated schools. ${ }^{63}$ This study used an experimental criterion of interracial behavior in examining the quality of interracial interaction among children who had experienced desegregation. Twelve four-person biracial groups of third grade boys who had participated in a voluntary desegregation plan were contrasted with twelve biracial groups who attended segregated elementary schools. The groups were given non-academic tasks to perform which demanded that the members work closely together. In both types of groups, whites were more likely to be active at the task than blacks. If anything, the whites who had experienced integration were more likely to dominate the blacks than were the whites who had attended segregated schools.

By contrast, other studies of schools in which interracial contact occurs suggest that favorable social learning does take place and black and white students learn to treat each other as individuals rather than as members of racial categories. Can these studies help to answer the question: what are the conditions under which the second of the two outcomes of interracial behavior will occur, instead of the first, in which racial stereotypes were reinforced?

The knowledge that a school has 20 per cent black students tells us nothing about the critical conditions in that organization favoring one type of social interaction over another. The school must be analyzed in its organizational context as an institution which strongly structures the nature of the contact between the races. Furthermore, the relationships of students of different races within the school must be examined in the context of interracial relationships in society outside the institution of education.

Several studies indicate that the school, as presently structured, does not present many opportunities for interracial interaction. Purely social groupings are likely to be racially segregated. ${ }^{64}$ Social segregation of the races is found even in a school where the staff is interracial and there are strong staff commitments and ${ }^{9}$ efforts toward true integration. ${ }^{65}$ The ordinary classroom does

63. J. Seidner, Effects of Integrated School Experience on Interaction in Small Bi-Racial Groups, 1971 (unpublished doctoral dissertation at the University of Southern California).

64. See J. Silverman \& M. Shaw, Effects of Sudden Mass School Desegregation on Interracial Interaction and Attitudes in One Southern City, Apr. 1971 (paper presented at the Eastern Psychological Association Annual Meeting in New York, N.Y.); P. Cusick \& R. Ayling, Racial Interaction in an Urban, Secondary School, Feb. 1973 (paper presented at American Educational Research Association in New Orleans, La.).

65. See M. Lachat, A Description and Comparison of the Attitudes of White High School Seniors Toward Black Americans in Three Suburban High Schools: An All White, a Desegregated, and an Integrated School, 1972 (unpublished doctoral dissertation at Teacher's College, Columbia University). 
not utilize much student interaction; classrooms are typically teacherdominated-especially in secondary schools. These are aspects of "life in classrooms" irrespective of the racial mixture of the class. However, one study has found a significant decrease-after a year of desegregation-of student talk, student-initiated talk, and student-to-student verbal interaction. ${ }^{66}$ The study also showed an increase in drill and structured instruction after desegregation, suggesting that teachers respond to desegregation by instruction in more traditional and even more teacher-dominated ways, thereby providing even fewer opportunities for interracial interaction than might otherwise have been the case.

A recent study suggests that the differential in socioeconomic status between whites and blacks may be instrumental in preventing equal status interaction. ${ }^{67}$ The researchers apply Allport's conditions for reducing prejudice to a sample of interracial classrooms, using an overall classroom measure of interracial acceptance as an indicator of racial prejudice. They state that the ideal classroom test of the contact theory would involve: ${ }^{68}$

gathering of longitudinal data in order to compare the development of interracial acceptance among groups of children differentiated according to (1) duration of desegregation; (2) majority group/minority group ratio in the classroom; (3) equality of majority/minority group status in regard to family background and academic achievement; and (4) racial attitudes of the classroom teacher and his or her ability to show each pupil respect, attention, and expectation of success, and to stress cooperation in pursuit of common goals rather than competition in pursuit of scarce goals.

A cross-sectional design was used in this study although this was supplemented with early grade records and week-long observations in the classrooms. Thirty-four interracial classrooms in eighteen schools, drawn in a random stratified sample of racially mixed elementary schools, were studied. Utilizing multiple regression (correlational) techniques, the researchers attempted to determine the extent to which each of the following factors contributes to children's interracial friendliness: the degree to which the child's previous schooling was desegregated, present classroom racial composition, the difference between whites and blacks in social class level, the achievement differential between races, and the teacher's behavioral style. Whether or not a child's previous schooling was desegregated and the present classroom racial composition were found not to be important predictors of interracial friendliness once the other factors were held constant. On the other hand, the smaller the white/black differential in class, the greater was the interracial

66. W. Coats. A Longitudinal Survey of Desegregation in Kalamazoo, Michigan, Sept. 7, 1972 (paper presented at the American Psychological Association Annual Convention, Honolulu, Hawaii).

67. N. St. John \& R. Lewis, supra note 54.

68. Id. at 80 . 
friendliness. This factor was the most powerful predictor in the study. It should be noted, however, that it is difficult, if not impossible, to disentangle this class differential from the achievement differential between blacks and whites. ${ }^{69}$ In a classroom where there is no great differential among students in socioeconomic status, there is likely to be only a small achievement differential.

In a subsequent analysis of the same data, ${ }^{70}$ it was found that, on an individual level, high academic performance contributed significantly to popularity of white and black children among children of both races.

It appears that the organizational context of the school also may have important effects on the quality of interracial relations. A study of attitudes of white high school seniors toward black Americans was undertaken in three suburban high schools. ${ }^{71}$ One school was an all-white high school while the other two were racially mixed. The purpose of the study was to distinguish between an integrated setting which seeks to facilitate positive interaction of a racially mixed student body and a desegregated setting not characterized by such practices. In the "integrated" high school, 71 per cent of the white seniors had favorable attitudes toward blacks, while only 37 per cent of the white seniors at the "desegregated" high school had favorable attitudes toward blacks. The all-white school was intermediate in favorability. These two contrasting schools were similar in terms of ethnic groups and socioeconomic levels. The integrated school had a racially balanced staff, a conscious staff commitment to deal with problems of integration, and utilized heterogeneous grouping procedures. The social studies and English departments instituted courses and units relating to the black experience. Teachers expressed a desire to provide classroom encounters that would erase stereotypes and myths. By contrast, the desegregated school had none of these features. The hypothesis to be drawn from this study is that mere desegregation is a necessary but not a sufficient condition for attaining desired goals concerning interracial attitudes and behavior.

An observational study of the social adjustment of both black and white newcomers to a school concluded that more important than the race of the student or his socioeconomic status in determining adjustment and assimilation in the new school was the particular educational environment of the school and the leadership of the principal. ${ }^{22}$ Another observational study of an urban high school that had a history of racial discord came to the conclusion that rigid structuring of interaction in the school, designed to prevent further hostility, also had the unwitting function of perpetuating the social distance between the races. ${ }^{73}$

69. $I d$.

70. St. John \& Lewis, supra note 58.

71. M. Lachat, supra note 65

72. C. Willie \& J. Beker, Race Mixing in the Public Schools (1973).

73. P. Cusick \& R. Ayling, supra note 64. 


\section{IV}

\section{The Utility of Applied Research With a Theoretical Base}

This article has examined social science research which began with the existence of desegregation or racial mixing in schools as a starting point and which then tried to disentangle its "effects." In the process of reviewing this research literature, those studies that hypothesize a concept which will explain why desegregation should have different consequences under different sets of conditions have been highlighted. These explanatory theories, although helpful, are not sufficiently developed so that any degree of certainty can be attributed to the cause-effect propositions put forth.

A completely different research strategy has been developed, however, which may prove better at identifying the essential conditions for the desired results of the desegregation process. Thus there is a series of studies which begins with a phenomenon and identifies this phenomenon as an instance of reasonably well-developed sociological theory and moves from laboratory studies to field studies.

\section{A. Interracial Interaction Disability}

Since 1968, I have been working with the problem of producing equal status behavior in interracial groups of students working together on tasks. The source of the problem-a phenomenon termed "interracial interaction disability" - was identified in the initial study. ${ }^{74}$ White and black male junior high school students were brought together in four-person groups to play a game requiring them to make decisions as a team. A pattern of white domination was observable despite the fact that the players had no basis for expecting special competence in the game from previous knowledge of the task, from knowledge of each other, or from perceived relevance of the task to school performance.

This pattern of white dominance was identified as a consequence of expectations of greater competence for higher status group members; expectations held by both black and white students. These initial expectations were activated by the differential in racial status, resulting in observably different rates of contribution to the task, and ultimately, in differential rates of influence, with the prestige and peer ranking of the groups replicating the status ranking or order of society at large. It is important to note that these children were matched in every respect except race-socioeconomic status, height, attitude toward school-and yet stereotypical expectations were fulfilled and reinforced.

In a study of college students, this same pattern of white dominance in interracial groups was found..$^{75}$ The black college students being studied dis-

74. Cohen, Interracial Interaction Disability, 25 Human Relations 9 (1972).

75. Katz \& Benjamin, Effects of White Authoritarianism in Biracial Work Groups, 61 J. A bNormal \& 
played marked social inhibition and subordination to their white partners in a cooperative problem-solving situation. Even when subjects were matched as to intelligence and were made to display equal ability on certain group tasks, blacks ranked whites higher on intellectual performance.

My own study was based on the theory of status characteristics and expectation states. ${ }^{76}$ Expectations stemming from status characteristics are part of our culture: it is generally believed that men are more competent than women, that adults are more competent than children, and that whites are more competent than blacks. These beliefs may be consciously or unconsciously held, but given certain conditions, they can infect new situations so that the prestige and power order in the new situation resembles the status order in the larger society.

From my initial study of interracial interaction disability, the inference may be drawn that even though blacks and whites might be brought together in a desegregated school in an "equal status" manner, it is still quite possible for the racial difference to act as a strong status differential triggering expectations for whites to do better in a new situation and for blacks to do less well. If this occurs in the school situation, then the racial stereotypes which contribute to these expectations are only reinforced and confirmed by the interracial interaction in the desegregated school. ${ }^{77}$ It should be a matter of great concern if the process of desegregation actually does result in reinforcing such stereotypes of racial incompetence.

It is important to note that these expectations are not necessarily consciously held by the participants. It is quite possible for a white person to express racial tolerance in response to an appropriate questionnaire or racial attitude survey, and still hold unconscious racist expectations. This ideologically tolerant individual can behave dominantly and insensitively in the interracial setting. Also, it is important to note that the origin of the problem lies in the beliefs and expectations of both blacks and whites. It is not a problem of "lack of assertiveness" of blacks alone, to be treated by compensatory education. Nor is it a problem of bigotry and miseducation of whites alone, to be treated with a seminar in black history or other intellectual multicultural methods.

\section{B. Expectation Training}

Having identified the problem as an instance of what is called a "diffuse status characteristic," an application of the theory could produce truly equal status behavior. When a group behaves in an "equal status" manner, one cannot tell from a person's color the amount of influence he will exert on the

Social. Psychology 448 (1960); Katz, Goldston, \& Benjamin, Behavior and Productivity in Biracial Work Croups, 11 Human Relations 123 (1958).

76. See Cohen, supra note 74. The general theory was developed earlier in Berger, Cohen, \& Zelditch, Status Characteristics and Expectation States, in Soctological Theories in Progress 29 (J. Berger ed. 1966).

77. See J. Seidner, supra note 63. 
particular experimental task assigned to the group. "Expectation training" was designed to treat those initial expectations with which blacks and whites enter a new situation.

The black children involved in the experiment came to the laboratory earlier than the white children. They were taught how to build a two-transistor radio and how to teach its construction to someone else. Then the white children were brought in and the interracial groups were shown a videotape of their prospective young black teachers assembling the radio set and explaining its operation. Each black child then taught a white child how to build the radio. Following this experience, a four-person, interracial group was assembled and instructed in the decision-making game used in previous studies. Those groups which were treated with "expectation training," did not show the pattern of white dominance characteristic of untreated groups. ${ }^{78}$ Equally important in this experiment was a situation in which the black students were taught how to build the radio, but then taught a black administrator instead of a white peer. These black students received just as much success experience and reinforcement as those who taught white students, but in this part of the experiment, the expectations of the white students went totally untreated. They were brought in just before instructions for the decision-making game were presented. The result was white dominance as much as in the case of wholly untreated groups. This suggests that the problem can not be resolved only by treating expectations of blacks; the whites must be treated as well.

In Oakland, during the summer of 1972, I operated the Center for Interracial Cooperation in a junior high school that had been experiencing severe problems of interracial friction. ${ }^{79}$ Two contrasting treatments were used to produce equal status interracial behavior. One was a version of "expectation training," with black students trained to teach white students in four different tasks. Instruction was conducted over five weekday mornings. The white students had a different black teacher for each of the four tasks. An alternative treatment involved the same tasks, but learning took place in small interracial groups under the supervision of an interracial teaching team. Teachers and teacher aides on this team saw to it that each child was successful in learning the four tasks and that the classroom was totally non-competitive.

Following these two treatments, we held four weeks of classes in which the children, still separated by the treatment they had experienced, were assigned to sex-segregated interracial classrooms under the supervision of interracial teaching teams. Here they studied a curriculum which did not demand reading and writing, although the tasks were of an intellectual and creative character. Students carried out their instructional tasks in small interracial groups; each

78. See Cohen \& Roper, Modification of Imterracial Interaction Disability: An Application of Status Characteristic Theory, 37 Am. Sociological Rev. 643 (1973).

79. See Cohen, Katz. \& Lohman. Center for Interracial Cooperation: A Field Experiment (to be published in Socrology of ED. in 1975). 
group, rather than the individual, was responsible and accountable for the group product. Even though there was a sharp social class and achievement differential between middle class whites and inner-city blacks in this study group, both races participated actively.

The experimental design provided for evaluation of "intergroup relations" immediately after the initial treatment and once again at the end of six weeks. Equal status behavior was maintained successfully throughout the summer school session both for students who had experienced "expectation training" and for those who had experienced the alternative treatment.

\section{Application to the Integrated School}

To apply this laboratory work on "equal status experience" to groups of children separated by a wide social gulf, in a school setting where there is competition for scarce rewards and where there are typically large achievement differentials in conventional academic skills, will be extremely difficult. First, even if the children were all of the same race but entered schools with differential skills and aptitudes for the conventional curriculum, a status order based on classroom achievement would emerge which would be just as effective in triggering self-fulfilling prophecies as race. In other words, the achievement status which emerges in competitively structured classrooms is capable of infecting new situations so that those who have low achievement status will expect to do less well on any new task when combined with those students who have a higher achievement status in the classroom. A study of junior high school students revealed that the status ranking in a classroom based on perceived academic ability was capable of affecting interaction and influence on a new group task with no intellectual or academic components. ${ }^{80}$ There is also evidence that competition aggravates the effect of diffuse status characteristics such as age or race. ${ }^{81}$

There are several other factors which make the desegregated school a very difficult place in which to produce equal status interaction. Of prime importance is the nature of the conventional curriculum. At the junior high school level, almost every subject requires the student to exhibit reading, writing, or computational skills in order to achieve satisfactory grades. Thus, if students enter a desegregated situation with a lower level of skills, they will be perceived as having little academic ability in almost every class they attend, even where there is no tracking or ability grouping. Analysis of the curriculum content reveals that aside from the overlap from subject to subject of required skills,

80. D. Hoffman \& E. Cohen, An Exploratory Study to Determine the Effects of Generalized Academic Performance Expectations Upon the Activity and Influence of Students Engaged in a Group Simulation Game, 1972 (paper presented at the American Educational Research Association in Chicago, Ill.).

81. See B. Awang Had, Effects of Status and Task Outcome Structures Upon Observable Power and Prestige Order of Small Task-Oriented Groups, 1972 (unpublished doctoral dissertation at Stanford University). 
only a very narrow range of mental abilities is dealt with in our public schools-there is a strong emphasis on convergent right-answer thinking and recitation in standard English. Furthermore, from kindergarten through high school, curricula are geared to the socialization practices of the middle class. ${ }^{82}$ Another factor which may be of vital importance is the presence of interracial classroom teams of teachers and a school administrative structure which is carefully balanced between black and white throughout its ranks.

The findings from these "equal status" experiments accomplish the following:

1. They suggest why desegregation has not been uniformly accompanied by interracial cooperation and improved black achievement.

2. They explain why, even when the conditions postulated by Allport as necessary for equal status contact exist ${ }^{83}$ one can still anticipate the effects of racism in American society inside the desegregated school.

3. They suggest that expensive and radical changes in the social structure of the school and its curriculum content may be necessary.

4. They provide a way to analyze particular integrated school situations as to the conditions that trigger self-fulfilling prophecies.

5. They provide a rigorous behavioral method of measuring whether interracial behavior at a given interracial school is of the "equal status" variety.

6. They specify the situations to which experimental results are generalizable.

\section{$\mathrm{V}$}

\section{Interracial Attitudes and Behavior: Some Useful Questions}

This review of the available social science research on the psychosocial effects of desegregation has shown the inutility of such research as support for limiting or expanding the nature of the remedy sought in school desegregation litigation or for a particular desegregation plan. For every study showing certain effects, another study reaching opposite results can be cited. This review of the available social science research literature has revealed that the findings are of such a mixed character that any attempt to use this evidence on the psychosocial effects of desegregation in a court could easily be contradicted by citing another study with opposite results. Furthermore, many of the studies are only of tangential interest to the courts.

I have tried to go beneath these generalizations to determine reasons for this state of affairs. One problem I have discussed is the failure to disentangle value questions from empirical questions. Thus one of the principal difficulties in resorting to studies of the sort reviewed in this article, in those areas where

82. E. Cohen, An Experimental Approach to School Effects, Feb. 1, 1974 (paper presented at the Western Sociology of Education Association in Monterey, Cal.).

83. See G. Alt.por't, supra note 15. 
there will be legal consequences, lies in this failure to separate issues involving value judgments from empirical questions. Many of the implicit value goals of researchers are not relevant to the issues before the courts--for example, the interest of social scientists in the reduction of white prejudice as a goal of integration.

A second problem with the research reviewed here lies in its lack of any theoretical explanation of why desegregation should have any effect, positive or negative, on interracial attitude and behavior. In a scientific sense, the studies reviewed have given very little thought to what kind of a phenomenon desegregation represents; widely differing social settings and contexts are selected for study of the "effects" of desegregation. Equally important is the lack of systematic attention, in the studies reviewed, to the process inside desegregated schools which will lead to attitude change or to desirable or undesirable interracial behavior.

Studies which have looked at outcome variables on a school-by-school basis strongly suggest that different schools under the same desegregation plans may result in very different states of interracial attitudes and behavior among students. In some cases, desegregation may result in self-fulfilling prophecies whereby the pattern of white dominance in society at large is clearly reflected within the schools. In other schools, staff commitment, principal leadership, and deliberate planning for interracial understanding appear to be associated with more favorable outcomes. Certainly, the studies suggest that the conventional school structure does not present many opportunities for interracial interaction. If it is true that there are critical pre-conditions for desegregated schools to achieve favorable interracial behavior, and if the studies of desegregation have no theory by which they can classify schools into those in which the essential conditions are met and those where they are not, the research to date is not likely even to become cumulative as to the effects of desegregation. Furthermore, until there is some idea of the process which accounts for the effect of the antecedent events on the resulting consequences, there is no way to tell which variables it is essential to control. It is always possible to argue that control of another variable would have changed the results. Finally, until a theory is developed sufficiently so that suitable indicators of particular concepts may be inferred, there is no way to decide whether a particular measure is appropriate. In other words, no matter how large the sample, no matter how many statistical controls are employed, and no matter how elaborate the statistical analysis, information about the "effects of desegregation" cannot be obtained with any reasonable level of certainty.

In sum, questions as to the effects of desegregation are essentially unanswerable with the tools of social science. By contrast, some more useful and answerable questions have been posed in this article. Local decision-making studies which contrast the current state of interracial relations in each school experiencing court-ordered desegregation can be useful. Studies of the fears 
and conflicts in the wake of an order to desegregate can produce the information necessary to make wise decisions as to those schools which will need support, pressure, and attention.

The other type of answerable question advocated here is a question as to the types of conditions under which it is more likely that a valued outcome can be achieved. If the question is phrased in this fashion, there are some outcomes such as equal status behavior between blacks and whites which might be desirable outcomes from desegregation orders and plans.

Applied research, such as that described in this article, would also enable one to determine to what extent integrated schools have approximated the model of those conditions which lead to equal status interaction. It would even permit interracial interaction to be measured in the relatively narrow and specific sense of whether or not there is a pattern of white dominance. If such a measure were utilized, it would undoubtedly reveal that very few programs are producing equal status behavior. ${ }^{84}$

In conclusion, the understanding gained from more theoretically oriented social science research could indirectly become influential upon the law. At the very least, it would become clear that schools, as they are presently constituted, are severely limited in bringing about desired social change. Perhaps courts and other decision makers would come to realize that trying to change the status order of an entire society by a superficial change in the racial composition of an organization which traditionally has reflected faithfully the power and status order in society at large is not an easy thing to do either politically or practically. There is no easy solution to the social integration of children in a society exhibiting segregation throughout its institutions. Yet if the society is willing to make the commitment to particular value goals, there is nothing in this research that says that schools cannot alter in such a way as to become more supportive of desired social change.

84. A possible exception might be that desegregated school in which militant race consciousness on the part of blacks would cause them to resist any white influence. It has been shown that this ideological state among blacks is associated with a weakening of the expectations for incompetence held by blacks. R. Newby, The Effect of Racial Consciousness of Black Youth on White Influence in Small Groups, 1974 (unpublished doctoral dissertation at Stanford University). 